ISSN: $1576-0162$

http://dx.doi.org/10.33776/rem.v0i58.4667

\title{
Comparative Re-Estimation of Environmental Degradation and Population Density in China: Evidence from the Maki's Regime ShifT Approach
}

REESTIMACIÓN COMPARATIVA DE LA DEGRADACIÓN AMBIENTAL Y LA DENSIDAD DE POBLACIÓN EN CHINA: EVIDENCIA DEL ENFOQUE DE CAMBIO DE RÉGIMEN DE MAKI

Muzzammil Hussain

Muzzammil.hussain@uog.edu.pk University of International Business and Economics, Beijing, China University of Gujrat, Gujrat, Pakistan

Nasir Mahmood Nasirmangat@yahoo.com Ningbo University of Finance and Economics, Ningbo, China

Fuzhong Chen uibesitechen@126.com University of International Business and Economics, Beijing, China

Zeeshan Khan zeeshan.17@sem.tsinghua.edu.cn Tsinghua University, Beijing, China

\author{
Muhammad Usman \\ Drusman@uog.edu.pk \\ University of Gujrat, Gujrat, Pakistan
}

Recibido: marzo 2020; aceptado: diciembre 2020

ABSTRACT

Numerous studies have estimated the linkage of economic growth and environmental degradation in the framework of EKC theory with typical $\mathrm{CO} 2$ emissions proxy. However, the complexity of environmental degradation (ED) is better measured by ecological footprint (ECF) in any geographical territory. Against this background, the present study is an effort to contribute to the existing literature by re-investigating the EKC hypothesis with ecological footprint and $\mathrm{CO} 2$ emissions proxy in the largest population of the world. Moreover, the role of population density is also considered with maximum data available from 1961 to 2016 for China. To estimate the said linkage, we apply 
first, second, and third-generation econometric approaches i. e. Augmented Dickey-Fuller unit root test, Zaviot Andrew's unit root test with structural breaks, and Carrion-i-Silvestre's general least-squares based test with several structural breaks. Likewise, the co-integration relationship is examined by applying Maki's co-integration econometric approach with multiple structural breaks. Furthermore, the autoregressive distributive lag model is applied to investigate the long-run and short-run relationships by incorporating year dummies highlighted by MBK. The results report the U-shaped EKC for China, which means economic growth is helping to clean the environment while the population density (PD) is found to be a cause of increasing ED. Findings have robust policy implications for China.

Keywords: Ecological footprint, $\mathrm{CO} 2$ emissions, Economic growth, Population density, GLS-based Carrion unit root, Maki co-intergradation, China.

\section{RESUMEN}

Numerosos estudios han estimado la relación entre el crecimiento económico y la degradación ambiental en el marco de la teoría de EKC con el proxy típico de las emisiones de CO2. Sin embargo, la complejidad de la degradación ambiental (DE) se mide mejor por la huella ecológica (ECF) en cualquier territorio geográfico. En este contexto, el presente estudio es un esfuerzo por contribuir a la literatura existente al volver a investigar la hipótesis de EKC con la huella ecológica y el proxy de las emisiones de CO2 en la población más grande del mundo. Además, el papel de la densidad de poblaciōn también se considera con los datos máximos disponibles de 1961 a 2016 para China. Para estimar dicha vinculación, aplicamos enfoques econométricos de primera, segunda y tercera generaciōn i. mi. Prueba de raíz unitaria de Dickey-Fuller aumentada, prueba de raíz unitaria de Zaviot Andrew con rupturas estructurales y prueba general basada en mínimos cuadrados de Carrion-i-Silvestre con varias rupturas estructurales. Asimismo, la relación de cointegración se examina aplicando el enfoque econométrico de cointegraciōn de Maki con múltiples rupturas estructurales. Además, el modelo de rezago distributivo autorregresivo se aplica para investigar las relaciones a largo y corto plazo mediante la incorporación de variables ficticias anuales destacadas por MBk. Los resultados informan el EKC en forma de U para China, lo que significa que el crecimiento económico está ayudando a limpiar el medio ambiente, mientras que se encuentra que la densidad de poblaciōn (PD) es una causa de aumento de la DE. Los hallazgos tienen importantes implicaciones políticas para China.

Palabras clave: huella ecológica, emisiones de CO2, crecimiento económico, densidad de poblaciōn, raíz unitaria de carroña basada en GLS, co-intergradaciōn maki, China.

JEL Classification/Clasificación JEL: C01, F64, 044, O54. 


\section{INTRODUCTION}

Environmental degradation (ED) has gained critical attention not only from environmental economists but among the general public as well (IPCC 2018). Historically, a linkage is developed between the economic activities and ED in the form of the Environmental Kuznets Curve (EKC) hypothesis (Grossman and Krueger 1995; Panayotou 1993). Afterward, many economists and environmentalists investigated the said-linkage with several related reasons in different parts of the world; the majority of them used traditional $\mathrm{CO} 2$ emissions as a measurement for the environment (Danish et al.; Dogan and Ozturk 2017; Hassan et al. 2019; Hussain, Mir, et al. 2020; Xu et al. 2018) the role of energy production in the pollution equation is largely unknown. The present work quantifies the relationship between energy production, economic growth and $\mathrm{CO} 2$ emission. A family of econometric tools is used to achieve the objective of the study. Due to the sensitivity of objective of the present work, we use structural break unit root test to measure the stability of parameters within the time span of 1970-2011. Johansen cointegration test confirms the existence of cointegration among variables. Autoregressive distributive lag model reveals that energy production from the fossil fuel is the main culprit behind growing $\mathrm{CO} 2$ emission. Additionally, the finding of the study claims the existence of environmental Kuznets curve hypothesis in the significance of energy production in Pakistan. Moreover, bidirectional causality is detected between energy production and carbon dioxide emission in the long-run path. It is suggested that pollution can be condensed by producing energy from the renewable source (hydropower, solar power, geothermal and wind energy. Nonetheless, these studies showed varied results, as some of them verified the existence of EKC but others did not support the EKC hypothesis. Although many reasons for ED are also explored to-date, however, the studies on the comparison of different ED proxies are scarce. Therefore, the objective of this study is to re-investigate the EKC hypothesis to compare the effect of economic growth and population density with ECF and CO2 emissions respectively in China. Thereby, finding the answers to the questions; whether the ECF and $\mathrm{CO} 2$ emissions are determining the similar nature of EKC or not? Moreover, what is the influence of PD in the ED of China?

Furthermore, in the different panel and single country investigations, inconclusive results of EKC with $\mathrm{CO} 2$ emissions are evident, e.g. In a comprehensive study of 144 countries, mixed results of EKC are reported 
(Ozturk, Al-Mulali, and Saboori 2016a). In a study on Asian panel countries EKC hypothesis is not verified (Liu, Zhang, and Bae 2017). The arguments on the EKC hypothesis by using CO2 emissions are continued, however, $\mathrm{CO} 2$ emissions represent a part of ED. Meanwhile, a comprehensive index of ED has also emerged as ECF and a few studies used ECF as a measure of ED to investigate the EKC hypothesis (Al-Mulali, Saboori, and Ozturk 2015; Destek and Sarkodie 2019; Dogan et al. 2020; Ozcan, Ulucak, and Dogan 2019a). Besides some studies paid attention to this phenomenon for China (He and Lin 2019; Miao et al. 2019; Xie, Xu, and Liu 2019); however, these studies did not compare the ECF and CO2 with PD.

Population density is the number of people resided per square $\mathrm{km}$ in a specific place. Being the overall ranked 81 st densely inhabited with a province with more than 3799 people per square km, China has 382 people per square $\mathrm{km}$ (Worldometers 2019). Moreover, China is the fastest-growing economy in the world and a substantial contributor to the world's $\mathrm{CO} 2$ emissions. Additionally, China is the most interesting economy to investigate based on these facts. World CO2 production reached 37.1 billion tonnes in 2018 , "Almost all countries are contributing to the rise, with emissions in China up $4.7 \%$, in the US by $2.5 \%$ and in India by $6.3 \%$ in 2018 . The EU's emissions are near flat, but this follows a decade of strong falls." (Jackson et al. 2018). Additionally, China also has the highest ECF in the world. In comparison with its bio-capacity, China is facing an ecological deficit as its ECF is much more than it owns (GFN, 2018).

This study has the following possible contributions to the literature. Firstly, this study is re-investigating the EKC hypothesis by incorporating the role of PD from 1961 to 2016 in China. Secondly, unlike others, comparative analysis of economic growth, PD, and EKC hypothesis with CO2 emissions and ECF is studied. Thirdly, the latest econometric methodology is applied i. e. first, second and third-generation unit root tests i.e. ADF, PP, ZA, and Carrion unit root techniques. Moreover, Maki co-integration with multiple structural breaks and ARDL bound testing with year dummies are applied (Carrion-i-Silvestre et al. 2009; Maki 2012; Pesaran, Shin, and Smith 2001 a)Econometrica 57, $1361-1401$. The rest of the paper is divided into the following four parts; In the first part, literature is review is given after that a comprehensive econometric methodology is discussed. The third part consists of discussions and finally, a conclusion with policy implications is given.

\section{LITERATURE REVIEW}

Many studies supported the nexus of environment and growth with multiple macroeconomic factors in the form of a panel and single country analysis. As a result of higher economic growth carbon emissions are decreased by $22 \%$ globally (Remuzgo and Sarabia 2015). Along with many others, energy intensity is found to be the key contributor to CO2 emissions in China (Ouyang and Lin 
Table1. Summary of Recent Literature on EKC

\begin{tabular}{|c|c|c|c|c|c|}
\hline Author(s), Year & Period & Country & ED Proxy & Methodology & Result \\
\hline $\begin{array}{l}\text { (Destek and Sarkodie } \\
\text { 2019) }\end{array}$ & $\begin{array}{l}1977- \\
2013\end{array}$ & $\begin{array}{l}11 \text { Newly industrialized } \\
\text { countries }\end{array}$ & $\mathrm{EF}$ & $\begin{array}{l}\text { AMG, Heterogeneous } \\
\text { Panel Causality }\end{array}$ & Yes \\
\hline (Hassan et al. 2019) & $\begin{array}{l}1984- \\
2014\end{array}$ & Pakistan & $\mathrm{CO} 2$ & ARDL & Yes \\
\hline (Fakher 2019) & $\begin{array}{l}1996- \\
2016\end{array}$ & 7 OPEC Countries & ECF & BMA \& WALS & Yes \\
\hline $\begin{array}{l}\text { (Awais and Wang } \\
\text { 2019) }\end{array}$ & $\begin{array}{l}1996- \\
2017\end{array}$ & BRICS & $\mathrm{CO} 2$ & $\begin{array}{l}\text { CIPS,CADF, DKSE, } \\
\text { DOLS, PMG }\end{array}$ & Yes \\
\hline $\begin{array}{l}\text { (Ulucak and Bilgili } \\
\text { 2018) }\end{array}$ & $\begin{array}{l}1961- \\
2013\end{array}$ & $\begin{array}{l}45 \text { High, middle and } \\
\text { low-income countries }\end{array}$ & EF & CUP-FM,CUP-BC & Yes \\
\hline (Danish et al. 2019) & $\begin{array}{c}1970- \\
2014\end{array}$ & Pakistan & $\mathrm{EF}$ & ARDL & Yes \\
\hline (Liu et al. 2017) & $\begin{array}{l}1970- \\
2013\end{array}$ & Asian countries Panel & $\mathrm{CO} 2$ & FMOLS, DOLS, OLS & No \\
\hline $\begin{array}{l}\text { (Sinha and Bhattacha- } \\
\text { rya 2017) }\end{array}$ & $\begin{array}{l}2001- \\
2013\end{array}$ & 139 Indian cities Panel & $\mathrm{SO} 2$ & Panel FE, RE & Mixed \\
\hline $\begin{array}{l}\text { (Danish, Zhang, et al. } \\
\text { 2017) }\end{array}$ & $\begin{array}{l}1970- \\
2012\end{array}$ & Pakistan & $\mathrm{CO} 2$ & $\begin{array}{l}\text { ARDL, FMOLS, DOLS, } \\
\text { CCR }\end{array}$ & Yes \\
\hline $\begin{array}{l}\text { (Dogan and Inglesi- } \\
\text { Lotz 2017) }\end{array}$ & $\begin{array}{l}1985- \\
2012\end{array}$ & $\begin{array}{l}\text { Biomass consuming } \\
\text { countries }\end{array}$ & $\mathrm{CO} 2$ & Panel FMOLS & Yes \\
\hline (Charfeddine 2017) & $\begin{array}{l}1970- \\
2015\end{array}$ & Qatar & $\begin{array}{l}\text { ECF \& Carbon } \\
\text { footprint }\end{array}$ & $\begin{array}{l}\text { Equilibrium model, } \\
\text { Markov Switching }\end{array}$ & Yes \\
\hline $\begin{array}{l}\text { (Aşıl and Acar 2016) } \\
\text { the existing Environ- } \\
\text { mental Kuznets Curve } \\
\text { (EKC }\end{array}$ & $\begin{array}{l}2004- \\
2008\end{array}$ & 116 countries & ECF & Panel FE & Yes \\
\hline $\begin{array}{l}\text { (Ozturk, Al-Mulali, and } \\
\text { Saboori 2016b) }\end{array}$ & $\begin{array}{l}1988- \\
2008\end{array}$ & $\begin{array}{l}144 \text { countries Time } \\
\text { series }\end{array}$ & ECF & GMM, S-GMM & Mixed \\
\hline (Al-Mulali et al. 2015) & $\begin{array}{l}1980- \\
2008\end{array}$ & 93 countries & ECF & Panel FE, GMM & Mixed \\
\hline Acar and As, ici (2015) & 2006 & 105 countries & ECF & Cross-section analysis & Yes \\
\hline (Ahmad et al. 2019) & $\begin{array}{l}1971- \\
2014\end{array}$ & China & $\mathrm{CO} 2$ & ARDL & No \\
\hline (Shahbaz et al. 2012) & $\begin{array}{l}1971- \\
2009\end{array}$ & Pakistan & $\mathrm{CO} 2$ & ARDL & Yes \\
\hline $\begin{array}{l}\text { (Ozturk and Al-Mulali } \\
\text { 2015) }\end{array}$ & $\begin{array}{l}1996- \\
2012\end{array}$ & Cambodia & $\mathrm{CO} 2$ & GMM, 2SLS & No \\
\hline $\begin{array}{l}\text { (Apergis and Ozturk } \\
\text { 2015) }\end{array}$ & $\begin{array}{l}1990- \\
2011\end{array}$ & 14 Asian countries & $\mathrm{CO} 2$ & $\begin{array}{l}\text { Panel co-integration, } \\
\text { FMOLS, DOLS, } \\
\text { PMG, MG }\end{array}$ & Yes \\
\hline (Nie et al. 2019) & $\begin{array}{l}1995- \\
2013\end{array}$ & China & $\mathrm{CO} 2$ & PSTR Model & No \\
\hline
\end{tabular}

Note: ECF \&CO2 are ecological footprint and Carbon dioxide emissions respectively.

Source: Author. 
2015). In India, the USA, Japan, and China; CO2 emissions are confirmed to be higher due to higher industrial production and economic growth (Azam et al. 2016). In Senegal, CO2 emissions are reported higher due to high urbanization, financial development, and industrialization(Asumadu-Sarkodie and Owusu 2017). In a recent study in Pakistan, institutions are found to be supportive to rectify the environmental degradation in the short and long run (Hassan et al. 2019). In the BRICS panel, CO2 emissions are influenced by the governance (Awais and Wang 2019). In an interesting case study of Pakistan, the role of PD is found supportive of ECF (Hussain, Usman, et al. 2020).

The second part of empirical studies comprises of the EKC hypothesis. For example, (Hassan et al. 2019; Mahmood, Wang, Yasmin, et al. 2019; Nasir and Ur Rehman 2011; Shahbaz, Zeshan, and Afza 2012) tested the validity of the EKC hypothesis in Pakistan. In another comprehensive study of 12 nuclear energy-focused countries, $\mathrm{CO} 2$ emissions are decreased by nuclear energy in the long run but the EKC hypothesis was found invalid (Baek 2015). While in Asian countries the EKC hypothesis is supported in a study by (Apergis and Ozturk 2015), similar results are also found for Africa (Sarkodie 2018). In India, the EKC hypothesis is also confirmed by (Shahbaz et al. 2013). Extant literature is evident in the fact that the EKC hypothesis is not new and studied by many environmentalists around the globe. However, the findings are not similar and policy implications are also diversified. This advocates the complication of the EKC hypothesis based on data periods, countries, and methodologies applied. Previous studies with two environmental proxies are summarized in table 1.

Above mentioned studies with different methodologies, time series, and panels are evidence of mixed results for the EKC hypothesis. Every study used only a single measure of ED and results is found to be varying from region to region, leading to inconclusive facts. So, in this study, we use two measures of ED to compare their robustness and to re-investigate EKC for China for the longest period. We also applied updated econometric techniques to calculate results.

\section{Methodology}

\section{1. THEORETICAL BACKGROUND AND DATA}

After the influential work of (Grossman and Krueger 1995), the environment and growth nexus is widely debated in the literature (Baloch et al. 2019; Danish et al. 2019; Destek and Sarkodie 2019; Ozcan, Ulucak, and Dogan 2019b; Shahbaz, Balsalobre-Lorente, and Sinha 2019; Solarin et al. 2018; Wang et al. 2018)it may be essential to quantify how renewable energy consumption influence process of human development. This particular area of research still needs to be explored. Thus, this paper explores the relationship between renewable energy consumption, economic growth and human development index for 1990-2014 in Pakistan by using Two-Stage Least Square (2SLS but 
studies are scarce in explaining the comparative analysis of $\mathrm{CO} 2$ emissions and ecological footprint in the environmental degradation with population density. Therefore, we intend to contribute to the existing nexus by adding the role of $\mathrm{PD}$ is to be investigated in the following form,

$$
\begin{aligned}
& \mathrm{LnECF}=\propto_{0}+\propto 1 \mathrm{LnGDP}+\propto 2 \mathrm{LnGDPSQ}+\propto 3 \mathrm{PD}+\mu \\
& \mathrm{LnCO}_{2}=\alpha_{0}+\propto 1 \mathrm{LnGDP}+\propto 2 \mathrm{LnGDPSQ}+\propto 3 \mathrm{PD}+\mu
\end{aligned}
$$

where ECF is ecological footprint consumption per capita, GDP is GDP per capita, GDPSO GDP is economic growth per capita square is used for EKC, PD is population density, and $\mu$ is the time (56 years) and $\mu$ is the error term. the natural log of all the variables is also calculated. Moreover, based on the previous literature, the coefficient of PD is assumed to be positive.

Annual data for the period 1961 to 2016 (the maximum available data) for China is used. Data of ECF "ecological footprint consumption per capita" is taken from " Global Footprint Network (GFN, 2018)”. Additionally, CO2 emissions are measured as the "CO2 emissions metric tons per capita", economic growth (GDP) is measured as "GDP per capita constant 2010 \$", population density (PD) is measured as "people per square kilometer of land area". Data on CO2 emissions, GDP, and PD is taken from the World Development indicator (WDI 2019).

\subsection{ECOnOmetric Strategy}

\subsubsection{Descriptive statistics and Stationarity Tests}

Data analysis starts with the descriptive statistics, in which the values of mean, median, standard deviation, and skewness are computed (see table 2a). Furthermore, to observe the stationarity of the data, we use first, second, and third-generation unit root tests. The first- and second-generation tests are unable to detect multiple time breaks in the data. To handle these issues (Carrion-i-Silvestre et al. 2009)Econometrica 57, 1361-1401 proposed a new approach and effectively solve the shortcomings of previous unit root tests. Carrion's unit root tests are evidenced to be much better than earlier and provide multiple structural breaks in the data in the following form.

$$
\begin{gathered}
Z_{t}=X_{t}+\varnothing_{t} \\
\varnothing_{t}=\alpha \varnothing_{t}+\pi_{t} \text { where } t=0, \ldots \ldots, T
\end{gathered}
$$

Following five tests are used to test the null hypothesis of stationarity:

$$
P_{T}\left(\vartheta^{\circ}\right)=\frac{\left[\left[\operatorname{SD}\left(\overline{\alpha,} \vartheta^{\circ}\right)-\bar{\alpha} \operatorname{SD}\left(1, \vartheta^{\circ}\right)\right]\right.}{\operatorname{SD}^{2}\left(\vartheta^{\circ}\right) \operatorname{SD}^{2}\left(\vartheta^{\circ}\right)}
$$

where is the spectral density and is the Gaussian point optimal statistics. 


$$
\begin{aligned}
& M P_{t}\left(\vartheta^{\circ}\right)=\frac{C^{-2} T^{-2} \sum_{t=1}^{T} \widetilde{Z_{t-1}^{2}}+(1-\bar{c}) T^{-1} \widetilde{Z_{T}^{2}}}{\operatorname{SD}\left(\vartheta^{\circ}\right)^{2}} \\
& M Z_{a}\left(\vartheta^{\circ}\right)=\left(T^{-2} \widetilde{Z_{T}^{2}}-\operatorname{SD}\left(\vartheta^{\circ}\right)^{2}\right)\left(2 T^{-2} \sum_{t=1}^{T} \widetilde{Z_{t-1}^{2}}\right)\left(2 T^{-2} \sum_{t=1}^{T} \widetilde{Z_{t-1}^{2}}\right)^{-1} \\
& \operatorname{MSB}\left(\vartheta^{\circ}\right)=\left(\operatorname{SD}\left(\vartheta^{\circ}\right)^{-2} T^{-2} \sum_{t=1}^{T} \widetilde{Z_{t-1}^{2}}\right)^{1 / 2} \\
& M Z_{t}\left(\vartheta^{\circ}\right)=\left(T^{-1} \widetilde{Z_{T}^{2}}-\operatorname{SD}\left(\vartheta^{\circ}\right)^{2}\right)\left(4 \operatorname{SD}\left(\vartheta^{\circ}\right)^{2} T^{-2} \sum_{t=1}^{T} \widetilde{Z_{t-1}^{2}}\right)^{1 / 2}
\end{aligned}
$$

\subsubsection{MAKI CO-INTEGRATION}

Although many co-integration techniques with structural breaks exist i.e. Hatemi-J's (2008) and Gregory and Hansen's (1996), they are not good enough in explaining the number of time breaks in the data. So, we opted for the MBk technique with the capacity of the maximum number of time breaks (Maki 2012)the proposed tests perform as well as the tests of Gregory and Hansen (1996a. Further, we employed the regime shift approach which allows for structural breaks in contributors $(\varnothing)$ and levels $(\partial)$, as well as the regime

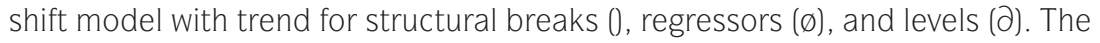
empirical equation form of is modelled as follows:

Regime Shift

Regime Shift with Trend

$$
C O 2_{t}, E C F_{t}=\partial+\sum_{i=1}^{k} \partial_{i} Z_{i t}+\tau t+\vartheta^{\prime} \varnothing_{t}+\sum_{i=1}^{k} \vartheta^{\prime} \varnothing_{i} Z_{i t}+\varepsilon_{t}
$$

$$
C O 2_{t}, E C F_{t}=\mu+\sum_{i=1}^{k} u_{i} z_{i t}+\pi t+\sum_{i=1}^{k} \Pi_{i} t Z_{i t}+\alpha^{\prime} x_{t}+\sum_{i=1}^{k} \alpha_{i}^{\prime} x_{i} Z_{i t}+u_{t}
$$

Where, $C O 2_{t} \& E C F$ are dependent variables; $t$ is the period of the study, as $t=1, \ldots \mathrm{T}$; and $\varnothing_{t}=\left(\varnothing_{1 t} \ldots \varnothing_{m t}\right)$ are contributors (economic development, the square of GDP to measure the EKC hypothesis, and population density). Furthermore, the $Z i_{t}$ is 1 if $t>T_{B I}(i=1, \ldots K)$ and $=0$ if $<T_{B I} T_{B I}$, which means structural break years, while $K$ is the number of lags.

\subsubsection{The ARDL Bounds Testing}

ARDL bounds testing is also applied to examine short- $\&$ long-run relationships between ECF, CO2 emissions, GDP, the square of GDP, and PD. Dummies suggested in co-integration are also included. Co-integration for the variables, that are integrated at I (1) or I (0) is dealt with by the ARDL approach, it also ensures unbiased results. It handles autocorrelation and solves indigeneity issue, and lags are automatically selected by it (Danish, Wang, and Wang 2017; Mahmood, Wang, and Hassan 2019). Following Hassan et al. (2019); Pesaran 
et al. (2001a); Shahbaz et al. (2013) the specification of both models for the "ARDL bounds testing approach" to co-integration is as follows:

$$
\begin{aligned}
& C O 2=f\left(G D P_{t},(G D P S Q)_{t}, P D_{t}, D_{1} 1979_{t}, D_{2} 1991_{t}, D_{3} 2001_{t}\right) \\
& E C F_{t}=f\left(G D P_{t},(G D P S Q)_{t}, P D_{t}, D_{1} 1991_{t}, D_{2} 2001_{t}, D_{3} 2009_{t}\right)
\end{aligned}
$$

where all the variables are the same as in equation- $1 \& 2$ and these $D_{1} 1991, D_{2}$ 2001, and $D_{3} 2009$ are year dummies. The general form of the ARDL is as follows:

$$
\begin{aligned}
& \Delta \mathrm{CO}_{t}=\alpha_{0}+\gamma_{1} \mathrm{CO}_{(t-i)}+\gamma_{2} G D P_{(t-i)}+\gamma_{3} G_{D P S} Q_{(t-i)}+\gamma_{4} P D_{(t-i)}+\theta_{1} D 1979_{(t-i)}+\theta_{2} D 1991_{(t-i)}+
\end{aligned}
$$

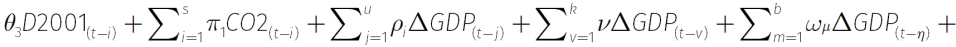

$$
\begin{aligned}
& \sum_{m=1}^{b} \psi_{1} \Delta D 1979_{(t-\mu)} \sum_{q=1}^{l} \phi_{1} \Delta D 1991_{(t-q)}+\sum_{c=1}^{h} \varpi_{c} \Delta D 2001_{(t-c)}+\varepsilon_{t} \\
& \Delta E C F_{t}=\alpha_{0}+\gamma_{1} E C F_{t-i}+\gamma_{2} G_{D P}+\gamma_{t-i} G_{3} D S Q_{t-i}+\gamma_{4} P_{t-i}+\theta_{1} D 1991_{t-i}+\theta_{2} D 2001_{t-i}+
\end{aligned}
$$

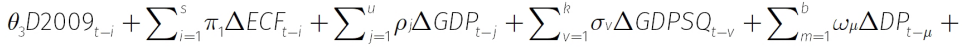

$$
\begin{aligned}
& \sum_{m=1}^{b} \psi_{s} \Delta D 1991_{t-\mu}+\sum_{q=1}^{l} \phi_{q} \Delta D 2001_{t-q}+\sum_{c=1}^{h} \varpi c \Delta D 2009_{t-c}+\varepsilon_{t}
\end{aligned}
$$

In equation-13\&14, $\alpha_{0}$ is the intercept in the model, while $\pi_{i}, \rho_{j}, \sigma_{v}$, $\tau_{w}$, and $\omega_{\mu}$ are coefficients. Similarly, $\psi_{s}, \varnothing_{q}$, and $\varpi_{c}$ are the dummy variables and short-run parameters in the model. The long-run parameters are represented by $\gamma_{1}, \gamma_{2}, \gamma_{3}, \gamma_{4}, \gamma_{5}, \theta_{1}, \theta_{2}$, and $\theta_{3}$. The null hypothesis suggests no cointegrating relationship between financial development and its determinants including $D_{1} 1991_{t}, D_{1} 2008_{t}$, and $D_{1} 2010_{t}$. The decision to accept or reject the null hypothesis is based on the calculated ADRL-F statistic (Pesaran et al. 2001 a). The hypotheses of the model are given as follows:

$H_{0}: \gamma_{1}=\gamma_{2}=\gamma_{3}=\gamma_{4}=\gamma_{5}=\theta_{1}=\theta_{2}=\theta_{3}=0$

$H_{1}$ : At least one is different

Similarly, if ARDL-F statistic shows a co-integration relationship among variables then the following long-run equation for the model is estimated:

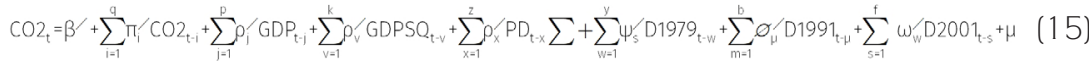

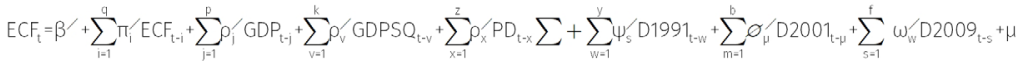

$\pi^{\prime}, \rho_{j}^{\prime}, \rho_{v}^{\prime}, \rho_{x}^{\prime}, \tau_{w}^{\prime}, \psi_{s}^{\prime}, \varnothing_{\mu}^{\prime}$, and $\omega_{w}^{\prime}$ are long - run coefficients., in equations $15 \& 16$ The short-run form of the model with the "error correction mechanism (ECM)" is as follows:

$$
\begin{aligned}
& \Delta \mathrm{CO}_{t}=\beta^{*}+\sum_{i=1}^{q} \pi_{i}^{*} \Delta \mathrm{CO}_{t-i}+\sum_{i=1}^{0} \rho_{i}^{*} \Delta G D P_{t-j}+\sum_{k=1}^{0} \rho_{v}^{*} \Delta G D P S Q_{t-v}+\sum_{i=1}^{n} \rho_{x}^{*} P D_{t-x} \\
& +\sum_{0=1}^{l} \psi_{s}^{*} \Delta D 1979_{t-5}+\sum_{\rho=1}^{h} \varnothing_{w}^{*} \Delta D 1991_{t-w}+\sum_{q=1}^{j} \varpi_{\mu}^{*} \Delta D 2001_{t-\mu}+\lambda E C M_{t-1}+\epsilon_{t} \\
& \Delta E C F_{t}=\beta^{*}+\sum_{i=1}^{q} \pi_{i}^{*} \Delta E C F_{t-1}+\sum_{j=1}^{p} \rho_{j}^{*} \Delta G D P_{t-j}+\sum_{k=1}^{0} \rho_{v}^{*} \Delta G D P S Q_{t-v}+\sum_{i=1}^{n} \rho_{x}^{*} P D_{t-x} \\
& +\sum_{\rho=1}^{1} \psi_{s}^{*} \Delta D 1991_{t-5}+\sum_{p=1}^{k} \varnothing_{W}^{*} \Delta D 2001_{t-w}+\sum_{Q=1}^{j} \varpi_{\mu}^{*} \Delta D 2009_{t-\mu}+\lambda E C M_{t-1}+\epsilon_{t}
\end{aligned}
$$

Short-run parameters are $\pi_{i}^{*}, \rho_{j}^{*}, \rho_{v}^{*}, \rho_{x}^{*}, \tau_{w}^{*}, \psi_{s}^{*}, \varnothing_{w}^{*}$, and $\varpi_{\mu}^{*}$; and $E C M_{t-1}$. 


\subsection{RESULTS AND INTERPRETATIONS}

Table 2 a reports a description of the data. The key measurements to know the description of the data are mean, median, standard deviation, and skewness. Descriptive statistics depicts the description results and associated graphs are clearly showing the data trends during the period of the study.
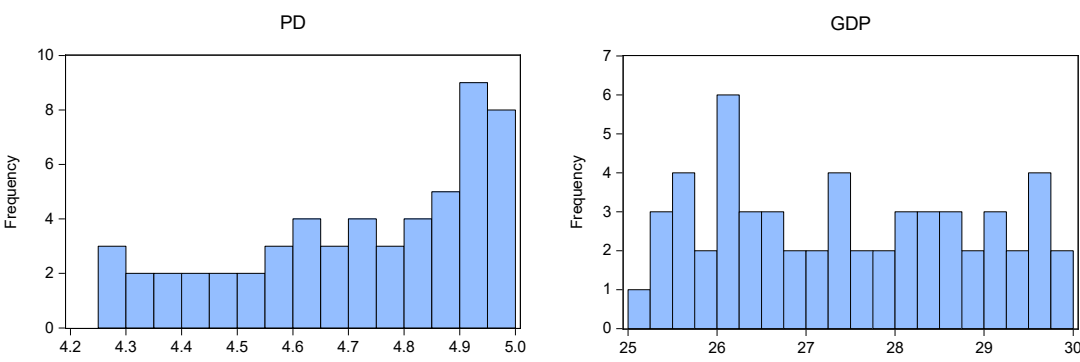

EF
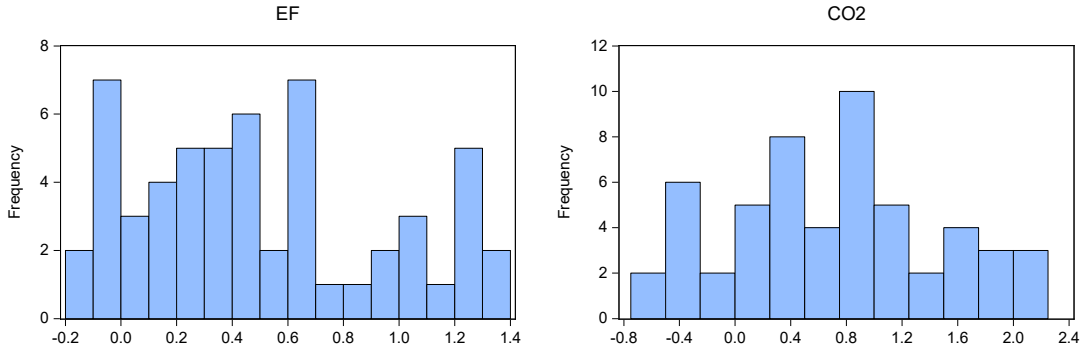

Table $2 \mathrm{~b}$ reports results for "augmented dickey fuller" (ADF) and "Phillips Pearson" (PP) without structural breaks. All variables are found integrated at first difference i.e. I (1), except population density, which is stationary at the level I (0) as well as on first difference I (1). Since ARDL allows mixed order of integration (Pesaran, Shin, and Smith 2001 b), such as I (0) and I (1) so we can proceed to pursue the long-run and short-run dynamics of the model. In table 3, the results of the second-generation unit root test with time break are reported (Zivot and Andrews 1992). According to the results, all the variables are stationary at the first difference I (1).

The results of Carrion unit root tests are reported in Table-4. The results show that ECF, CO2 emissions, GDP, and PD are non-stationary at level I (0) with multiple time breaks. As in the unit root results, calculated values at the level are greater than that of the tabulated values, so cannot reject the null hypothesis of stationarity, but after taking the first difference of all the variables, they become stationary, as the calculated values are shown are less than the tabulated values given in brackets. So it can be concluded that all the 
variables are stationary at the first difference (Carrion-i-Silvestre et al. 2009) Econometrica 57, 1361-1401. Time breaks in the series disclose key events in the economy of China.

As Carrion unit root test ensures multiple structural breaks in each series, so we cannot apply simple co-integration tests for examining the co-integration relationship between the variables such Gregory and Hansen (1996) and Hatemi-J (2008) performance is not good as compared to when the series has more than two breaks (Maki, 2012). Therefore, we apply co-integration approach for two models, the first model is applied with $\mathrm{CO} 2$ emissions as ED, and in the second model, the ECF is used as environmental degradation. Variables in both of the models are the same i.e. GDP, the square of GDP, and PD with three-time breaks. In table 5, the empirical results of by using $\mathrm{CO} 2$ are shown and suggest the presence of co-integrating both in regime shift and regime shift with the trend with breaks.

Further, to include the effect of breaks for CO2 emissions, we developed three dummies such as D, D2001, and D2009 from the regime shift model with a trend to trace whether its effect on $\mathrm{CO} 2$ emissions is positive or negative. For this purpose, we apply the "Autoregressive Distributed Lags model" (ARDL) with dummies. Similarly, in table 6, we computed the co-integration between EF, GDP, GDPSQ, and PD. The results of MBK co-integration with regime shift and regime shift with trend verify the co-integration between the ECF and the determinants. Furthermore, to include the time break's effect for ECF, we develop three dummies such as D, D2001 and D2009 from MBk's regime shift and trend approach to check their effects on ecological footprint. For this purpose, we apply the ARDL model with dummies. In table 7, the results of ARDL bound testing are given. Model-a is without the dummies of time breaks, while model-b includes the dummies. Similarly, model-c is without the dummies, and model-d is run with year dummies. The values of F-statistics of bounds tests are found to higher than the upper bound values in all the models, which suggests the significance of all the models. In other words, it is an indication of the co-integration of the hypothesized variables. Furthermore, based on these results, the ARDL model can be perused for the long- and short-run results.

Long- and short-run results are discussed in table $8 \&$ table 9. GDP is found to be statistically significant in all models in the long- $\&$ short-run. Interestingly, the coefficient of GDP is negative. It means that with the increase in economic growth, ED is decreasing for both environmental proxies in the long- and shortrun. ECF and $\mathrm{CO} 2$ emissions are decreasing with the increase in the economic growth of China. The coefficient of GDPSQt was found to be positive and statistically significant in the long- and short-run for China. These results of GDP and EKC are aligned with the studies by Destek (2019); Destek and Sarkodie (2019); Miao et al. (2019). Additionally, PD is also found to be statistically significant and its coefficient is positive in the long- and short-run, highlighting the burden of dense population on the environment. It means that the dense population is increasing the ED both in the form of high $\mathrm{CO} 2$ emissions and 
ECF in China. These results are backed by (Nasrollahi et al. 2018; Ribeiro, Rybski, and Kropp 2019; Zhou, Wang, and Wang 2019). But unlike previous studies, we also use ECF and CO2 emissions jointly to check the robustness of both measures.

Additionally, the year dummies for the structural breaks are also incorporated in the models to check the effect these years on ECF and CO2 emissions. Firstly, for CO2 emissions, D1979 is found to be negative and significant in the long as well as in the short-run. During the second half of the 1970s; China started focusing on environmental issues and launched "the first environmental protection law for trial implementation" in 1979 (Edmonds 1999). So, environmental considerations started just before this time break. The second dummy D1991 is also reported to be significant and the coefficient is positive in the long- and short-run. It means CO2 emissions and ECF are increased in this period, although insignificant with ecological footprint but the coefficient is still positive. China started promoting exports and due to higher industrial production, environmental degradation increased during that period. Similarly, D2001 was also found to be statistically significant with a positive coefficient in the long- and short-run. It means an increase in $\mathrm{CO} 2$ emissions and ECF. During that time, China's exports were continuously increasing, and consequently, ED also increased. Additionally, D2009 was found to be insignificant with a negative coefficient in the long- and short-run.

\subsection{DiSCUSSION ON FINDINGS}

Based on the results given in the results and interpretation section, the following discussion can be built to understand the findings for the audience who are unable to understand the statistical values used in this study. Starting from the stationarity properties of the data used, the first break dates are from 1977 to 1980 show the significant chapter of the Chinese economy which is the start of the economic reforms in China (Nie et al. 2019). Due to industrialization, environmental degradation started with economic reforms. The second time break appears from 1991 to 1994, which is also an important era in the history of China's economic development. The economic reforms of 1992 helped China to accelerate growth production for exports. Higher GDP targets pushed China towards higher environmental issues, which were realized later. Time break during 1999 to 2003, was also an important era for the Chinese economy, China signed Kyoto Protocol in 1998, and environmental considerations were taken into account and consequently, higher economic growth started to take steps to improve environmental issues.

MBK's co-integration results are indicating the PD, GDPSO, PD, and suggested time breaks are co-integrated with ECF and CO2 emissions in China. It means that in China the PD is responsible for the ED. Moreover, the suggested time breaks i. e. 1979, 1991, and 2001, and 2009 are found to be the years of higher economic activities and hence the high ECF and CO2 
emissions are reported. It can be inferred that due to higher export demands the production in industrial units was at the peak and high production results in greater ECF and CO2 emissions in China. Additionally, the long- and shortrun results of ARDL for ECF and $\mathrm{CO} 2$ emissions are also found to be robust. Moreover, the EKC is found to be U-shaped for China, which means that GDP is helping to decrease ED. Furthermore, China needs to spread the population evenly because the PD is found to be a major cause of the ecological deficit and high ECF and CO2 emissions.

\section{Conclusion and Policy Recommendations}

The study aims to compare the EKC hypothesis in the presence of a dense population of China for two proxies of ED i.e. ECF and CO2 emissions. We applied ADF, PP, ZA, and GLS-based Carrion unit root tests to study the stationarity properties of the data, which reveals multiple structural breaks, consequently, MBk co-integration is applied with multiple structural breaks and co-integration is verified. Year dummies suggested by MBK co-integration are incorporated in the ARDL bound testing to study their effect on ED. GDP is found to be negatively affecting ECF and CO2 emissions in the longand short-run, suggesting U-shaped EKC for China. It means China's GDP is helping to mitigate the pollution. PD is found to be positively affecting ECF and $\mathrm{CO} 2$ emissions. Unlike others, the suggested time breaks in the form of year dummies i. e. 1979, 1991, 2001, and 2009 are found substantially affecting the ED in China. Said years are verified as the turning points of the Chinese economy and consequently the environment of the country.

Based on these findings, the following policy recommendations can be offered. Firstly, the Chinese government should continue to improve the GDP growth rate to counter ED, as GDP growth is found to be effective for the environment in China. Higher GDP growth may help to save the environment and future sustainable development of China. Secondly, PD is high in China, as Shanghai is having 3800 people per square $\mathrm{km}$. Immediate policy reconsiderations may help to reduce CO2 emissions and ECF. Thirdly, environmental safety awareness programs by media and educational institutions may help to reduce environmental degradation in China.

\section{ACKNOWLEDGMENT}

This study was financially supported by the Research Project of the Center of Beijing Xi Jinping Thought of Socialism with Chinese Characteristics in the New Era (Grant No. 19LLLJB037), the National Natural Science Foundation of China (Grant No. 71603049), the Social Science Foundation of Ministry of Education of China (Grant No. 16YJC790006), the Program for Young Excellent 
Talents, UIBE (Grant No. 18YO07), and the Key Research Project Foundation of Beijing Finance Society.

\section{REFERENCES}

Ahmad, Najid, Liangsheng Du, Xian Liang Tian, and Jianlin Wang. 2019. "Chinese Growth and Dilemmas: Modelling Energy Consumption, CO2 Emissions and Growth in China." Quality and Quantity 53(1):315-38.

Al-Mulali, Usama, Behnaz Saboori, and Ilhan Ozturk. 2015. "Investigating the Environmental Kuznets Curve Hypothesis in Vietnam." Energy Policy 76:123-31.

Apergis, Nicholas and Ilhan Ozturk. 2015. "Testing Environmental Kuznets Curve Hypothesis in Asian Countries." Ecological Indicators 52:16-22.

Aşıcı, Ahmet Atıl and Sevil Acar. 2016. "Does Income Growth Relocate Ecological Footprint?" Ecological Indicators 61:707-14.

Asumadu-Sarkodie, Samuel and Phebe Asantewaa Owusu. 2017. "A Multivariate Analysis of Carbon Dioxide Emissions, Electricity Consumption, Economic Growth, Financial Development, Industrialization, and Urbanization in Senegal." Energy Sources, Part B: Economics, Planning and Policy 12(1):77-84.

Awais, Muhammad and Bo Wang. 2019. "Analyzing the Role of Governance in CO 2 Emissions Mitigation: The BRICS Experience." Structural Change and Economic Dynamics 51:119-25.

Azam, Muhammad, Abdul Qayyum Khan, Hussin Bin Abdullah, and Muhammad Ejaz Qureshi. 2016. "The Impact of CO2 Emissions on Economic Growth: Evidence from Selected Higher CO2 Emissions Economies." Environmental Science and Pollution Research 23(7):6376-89.

Baek, Jungho. 2015. "A Panel Cointegration Analysis of CO2 Emissions, Nuclear Energy and Income in Major Nuclear Generating Countries." Applied Energy 145:133-38.

Baloch, Muhammad Awais, Jianjun Zhang, Kashif Iqbal, and Zeeshan Iqbal. 2019. "The Effect of Financial Development on Ecological Footprint in BRI Countries: Evidence from Panel Data Estimation." Environmental Science and Pollution Research 26(6):6199-6208.

Carrion-i-Silvestre, Josep Lluís, Dukpa Kim, Pierre Perron, Josep Carrion-i-Silvestre, Dukpa Kim, and Pierre Perron. 2009. "GLS-BASED UNIT ROOT TESTS WITH MULTIPLE STRUCTURAL BREAKS UNDER BOTH THE NULL AND THE ALTERNATIVE HYPOTHESES." Econometric Theory 25(06): 1754-92.

Charfeddine, Lanouar. 2017. "The Impact of Energy Consumption and Economic Development on Ecological Footprint and CO2 Emissions: Evidence from a Markov Switching Equilibrium Correction Model." Energy Economics 65:355-74.

Danish, Syed Tauseef Hassan, Muhammad Awais Baloch, Nasir Mehmood, and JianWu Zhang. 2019. "Linking Economic Growth and Ecological Footprint 
through Human Capital and Biocapacity." Sustainable Cities and Society 47(March): 101516.

Danish, Bo Wang, and Zhaohua Wang. 2017. "Imported Technology and CO 2 Emission in China: Collecting Evidence through Bound Testing and VECM Approach." Renewable and Sustainable Energy Reviews (November): 1-11.

Danish, Bin Zhang, Bo Wang, and Zhaohua Wang. 2017. "Role of Renewable Energy and Non-Renewable Energy Consumption on EKC: Evidence from Pakistan." Journal of Cleaner Production 156:855-64.

Danish, Bin Zhang, Zhaohua Wang, and Bo Wang. "Energy Production, Economic Growth and CO2 Emission: Evidence from Pakistan." Natural Hazards 90(1).

Destek, Mehmet Akif. 2019. "Investigation on the Role of Economic, Social, and Political Globalization on Environment: Evidence from CEECs." Environmental Science and Pollution Research 1-14.

Destek, Mehmet Akif and Samuel Asumadu Sarkodie. 2019. "Investigation of Environmental Kuznets Curve for Ecological Footprint: The Role of Energy and Financial Development." Science of the Total Environment 650:248389.

Dogan, Eyup and Roula Inglesi-Lotz. 2017. "Analyzing the Effects of Real Income and Biomass Energy Consumption on Carbon Dioxide (CO2) Emissions: Empirical Evidence from the Panel of Biomass-Consuming Countries." Energy 138:721-27.

Dogan, Eyup and Ilhan Ozturk. 2017. "The Influence of Renewable and NonRenewable Energy Consumption and Real Income on CO2emissions in the USA: Evidence from Structural Break Tests." Environmental Science and Po/lution Research.

Dogan, Eyup, Recep Ulucak, Emrah Kocak, and Cem Isik. 2020. "The Use of Ecological Footprint in Estimating the Environmental Kuznets Curve Hypothesis for BRICST by Considering Cross-Section Dependence and Heterogeneity." Science of The Total Environment 723:138063.

Edmonds, Richard Louis. 1999. "The Environment in the People 's Republic of China 50 Years On Author ( s ): Richard Louis Edmonds Source: The China Quarterly, No . 159, Special Issue: The People' s Republic of China after 50 Published by: Cambridge University Press on Behalf Of." (159):640-49.

Fakher, Hossein Ali. 2019. "Investigating the Determinant Factors of Environmental Quality (Based on Ecological Carbon Footprint Index)." Environmental Science and Pollution Research.

GFN, 2018. n.d. "GFN, 2018." Retrieved June 24, 2019 (http://data.footprintnetwork. org/\#/countryTrends?type = BCtot,EFCtot\%26cn = 165).

Grossman, G. M. and A. B. Krueger. 1995. "Economic Growth and the Environment." The Quarterly Journal of Economics 110(2):353-77.

Hassan, Syed Tauseef, Danish, Salah Ud-Din Khan, Enju Xia, and Hani Fatima. 2019. "Role of Institutions in Correcting Environmental Pollution: An Empirical Investigation." Sustainable Cities and Society 101901. 
He, Yongda and Boqiang Lin. 2019. "Investigating Environmental Kuznets Curve from an Energy Intensity Perspective: Empirical Evidence from China.” Journal of Cleaner Production 234:1013-22.

Hussain, Muzzammil, Ghulam Mustafa Mir, Muhammad Usman, Chengang Ye, and Sadia Mansoor. 2020. "Analysing the Role of Environment-Related Technologies and Carbon Emissions in Emerging Economies: A Step towards Sustainable Development." Environmental Technology 1-24.

Hussain, Muzzammil, Muhammad Usman, Jawad Ahmad Khan, Zahid Hassan Tarar, and Muhammad Arslan Sarwar. 2020. "Reinvestigation of Environmental Kuznets Curve with Ecological Footprints: Empirical Analysis of Economic Growth and Population Density." Journal of Public Affairs (July).

IPCC. 2018. An IPCC Special Report: Global Warming of 1.5 C.

Jackson, R. B., C. Le Quéré, R. M. Andrew, J. G. Canadell, J. I. Korsbakken, Z. Liu, G. P. Peters, and B. Zheng. 2018. "Global Energy Growth Is Outpacing Decarbonization." Environmental Research Letters 13(12).

Liu, Xuyi, Shun Zhang, and Junghan Bae. 2017. "The Impact of Renewable Energy and Agriculture on Carbon Dioxide Emissions: Investigating the Environmental Kuznets Curve in Four Selected ASEAN Countries." Journal of Cleaner Production 164:1239-47.

Mahmood, Nasir, Zhaohua Wang, and Syed Tauseef Hassan. 2019. "Renewable Energy, Economic Growth, Human Capital , and CO 2 Emission: An Empirical Analysis."

Mahmood, Nasir, Zhaohua Wang, Nazia Yasmin, Waqas Manzoor, and Atteeq ur Rahman. 2019. "How to Bend down the Environmental Kuznets Curve: The Significance of Biomass Energy." Environmental Science and Pollution Research 1-11.

Maki, Daiki. 2012. "Tests for Cointegration Allowing for an Unknown Number of Breaks." Economic Modelling 29(5):2011-15.

Miao, Lu, Huijie Gu, Xiwei Zhang, Wei Zhen, and Mingyue Wang. 2019. "Factors Causing Regional Differences in China's Residential CO 2 Emissions-Evidence from Provincial Data." Journal of Cleaner Production 224:852-63.

Nasir, Muhammad and Faiz Ur Rehman. 2011. "Environmental Kuznets Curve for Carbon Emissions in Pakistan: An Empirical Investigation." Energy Policy 39(3): 1857-64.

Nasrollahi, Zahra, Mohadeseh-sadat Hashemi, Saeed Bameri, and Vahid Mohamad Taghvaee. 2018. "Environmental Pollution, Economic Growth, Population, Industrialization, and Technology in Weak and Strong Sustainability: Using STIRPAT Model." Environment, Development and Sustainability.

Nie, Yongyou, Qucheng Li, Enci Wang, and Tsangyao Zhang. 2019. "Study of the Nonlinear Relations between Economic Growth and Carbon Dioxide Emissions in the Eastern, Central and Western Regions of China." Journal of Cleaner Production 219:713-22.

Ouyang, Xiaoling and Boqiang Lin. 2015. "An Analysis of the Driving Forces of Energy-Related Carbon Dioxide Emissions in China's Industrial Sector." Renewable and Sustainable Energy Reviews 45:838-49. 
Ozcan, Burcu, Recep Ulucak, and Eyup Dogan. 2019a. "Analyzing Long Lasting Effects of Environmental Policies: Evidence from Low, Middle and High Income Economies." Sustainable Cities and Society 44:130-43.

Ozcan, Burcu, Recep Ulucak, and Eyup Dogan. 2019b. "Analyzing Long Lasting Effects of Environmental Policies: Evidence from Low, Middle and High Income Economies." Sustainable Cities and Society 44:130-43.

Ozturk, Ilhan and Usama Al-Mulali. 2015. "Natural Gas Consumption and Economic Growth Nexus: Panel Data Analysis for GCC Countries." Renewable and Sustainable Energy Reviews 51:998-1003.

Ozturk, Ilhan, Usama Al-Mulali, and Behnaz Saboori. 2016a. "Investigating the Environmental Kuznets Curve Hypothesis: The Role of Tourism and Ecological Footprint." Environmental Science and Pollution Research 23(2):191628.

Ozturk, Ilhan, Usama Al-Mulali, and Behnaz Saboori. 2016b. "Investigating the Environmental Kuznets Curve Hypothesis: The Role of Tourism and Ecological Footprint." Environmental Science and Pollution Research 23(2):191628.

Panayotou, T. 1993. "Empirical Tests and Policy Analysis of Environmental Degradation at Different Stages of Economic Development."

Pesaran, M. Hashem, Yongcheol Shin, and Richard J. Smith. 2001 a. "Bounds Testing Approaches to the Analysis of Level Relationships." Journal of Applied Econometrics 16(3):289-326.

Pesaran, M. Hashem, Yongcheol Shin, and Richard J. Smith. 2001 b. "Bounds Testing Approaches to the Analysis of Level Relationships." Journal of Applied Econometrics 16(3):289-326.

Remuzgo, Lorena and José María Sarabia. 2015. "International Inequality in $\mathrm{CO}<\inf >2</$ Inf $>$ Emissions: A New Factorial Decomposition Based on Kaya Factors." Environmental Science and Policy 54:15-24.

Ribeiro, Haroldo V, Diego Rybski, and Jürgen P. 2019 Kropp. n.d. "Effects of Changing Population or Density on Urban Carbon Dioxide Emissions."

Sarkodie, Samuel Asumadu. 2018. "The Invisible Hand and EKC Hypothesis: What Are the Drivers of Environmental Degradation and Pollution in Africa?" Environmental Science and Pollution Research 25(22):21993-22.

Shahbaz, Muhammad, Daniel Balsalobre-Lorente, and Avik Sinha. 2019. "Foreign Direct Investment-CO2 Emissions Nexus in Middle East and North African Countries: Importance of Biomass Energy Consumption." Journal of Cleaner Production 217:603-14.

Shahbaz, Muhammad, Qazi Muhammad Adnan Hye, Aviral Kumar Tiwari, and Nuno Carlos Leitão. 2013. "Economic Growth, Energy Consumption, Financial Development, International Trade and CO2 Emissions in Indonesia." Renewable and Sustainable Energy Reviews 25:109-21.

Shahbaz, Muhammad, Muhammad Zeshan, and Talat Afza. 2012. "Is Energy Consumption Effective to Spur Economic Growth in Pakistan? New Evidence from Bounds Test to Level Relationships and Granger Causality Tests." Economic Modelling 29(6):2310-19. 
Sinha, Avik and Joysankar Bhattacharya. 2017. "Estimation of Environmental Kuznets Curve for SO2 Emission: A Case of Indian Cities." Ecological Indicators 72:881-94.

Solarin, Sakiru Adebola, Usama Al-Mulali, Gerald Goh Guan Gan, and Muhammad Shahbaz. 2018. "The Impact of Biomass Energy Consumption on Pollution: Evidence from 80 Developed and Developing Countries." Environmental Science and Pollution Research 1-17.

Ulucak, Recep and Faik Bilgili. 2018. "A Reinvestigation of EKC Model by Ecological Footprint Measurement for High, Middle and Low Income Countries." Journal of Cleaner Production 188:144-57.

Wang, Zhaohua, Danish, Bin Zhang, and Bo Wang. 2018. Renewable Energy Consumption, Economic Growth and Human Development Index in Pakistan: Evidence Form Simultaneous Equation Model. Elsevier Ltd.

WDI. 2019. "Indicators | Data."

Worldometers, 2019. n.d. "Worldometers, 2019." Retrieved June 25, 2019 (https://www.worldometers.info/world-population/pakistan-population/).

Xie, Qichang, Xin Xu, and Xiaqing Liu. 2019. "Is There an EKC between Economic Growth and Smog Pollution in China? New Evidence from Semiparametric Spatial Autoregressive Models." Journal of Cleaner Production 220:873-83.

Xu, Zefeng, Muhammad Awais Baloch, Danish, Fanchen Meng, Jianjun Zhang, and Zahid Mahmood. 2018. "Nexus between Financial Development and CO2 Emissions in Saudi Arabia: Analyzing the Role of Globalization." Environmental Science and Pollution Research 25(28):28378-90.

Zhou, Chunshan, Shaojian Wang, and Jieyu Wang. 2019. "Examining the Influences of Urbanization on Carbon Dioxide Emissions in the Yangtze River Delta, China: Kuznets Curve Relationship." Science of the Total Environment 675:472-82.

Zivot, Eric and Donald W. K. Andrews. 1992. "Further Evidence on the Great Crash, the Oil Price Shock, and the Unit Root Hypothesis." Journal of Business \& Economic Statistics 10(3):251-70. 


\section{APPENDIX}

Table 2a. Descriptive statistics

\begin{tabular}{l|c|c|c|c} 
& PD & GDP & ECF & CO2 \\
\hline Mean & 4.711592 & 27.36018 & 0.476581 & 0.692033 \\
\hline Median & 4.757037 & 27.30939 & 0.415094 & 0.739030 \\
\hline Maximum & 4.978920 & 29.74935 & 1.319167 & 2.022502 \\
\hline Minimum & 4.253281 & 25.20155 & -0.111971 & -0.554843 \\
\hline Std. Dev. & 0.219754 & 1.373760 & 0.424887 & 0.738824 \\
\hline Skewness & -0.598498 & 0.159854 & 0.487928 & 0.118146 \\
\hline Kurtosis & 2.170970 & 1.770347 & 2.263206 & 2.185790
\end{tabular}

Table 2b. Unit root tests

\begin{tabular}{l|c|c|c|c} 
& \multicolumn{2}{|c|}{ Augmented Dickey-Fuller (ADF) } & \multicolumn{2}{c}{ Phillips Pearson (PP) } \\
\hline Variables & At Level & First Difference & At Level & First Difference \\
\hline $\mathrm{ECF}_{\mathrm{t}}$ & 0.079107 & $-5.348201^{* * *}$ & 0.88699 & $-5.268684^{* * *}$ \\
& $(0.9612)$ & $(0.0000)$ & $(0.9946)$ & $(0.0000)$ \\
\hline $\mathrm{CO}_{2} \mathrm{t}$ & -0.419462 & $-5.797054^{* * *}$ & 0.589843 & $-6.063907^{* * *}$ \\
& $(0.8978)$ & $(0.0000)$ & $(0.9882)$ & $(0.0000)$ \\
\hline $\mathrm{CDP}_{\mathrm{t}}$ & 0.008002 & $-5.907570^{* * *}$ & 2.479057 & $-6.257446^{* * *}$ \\
& $(0.9550)$ & $(0.0000)$ & $(1.0000)$ & $(0.0000)$ \\
\hline $\mathrm{PD}_{\mathrm{t}}$ & -2.668921 & $-3.894900^{* *}$ & -0.869654 & $-5.923423^{* * *}$ \\
& $(0.0870)$ & $(0.0200)$ & $(0.9520)$ & $(0.0000)$
\end{tabular}

Note: ${ }^{* * *},{ }^{* *},{ }^{*}$ are significance levels at $1 \%, 5 \%$ and $10 \%$ respectively.

Table 3. ZA Unit Root

\begin{tabular}{l|l|c|c|l|c|c} 
Variable & \multicolumn{1}{|l}{ At Level } & First Difference \\
\hline & T-Statistics & P-Value & Break Year & T-Statistics & P-Value & Decision \\
\hline $\mathrm{ECF}_{\mathrm{t}}$ & $-3.449150-$ & 0.365728 & 1996 & -6.639298 & $0.000765^{* * *}$ & $\mathrm{I}(\mathrm{I})$ \\
\hline $\mathrm{CO} 2_{\mathrm{t}}$ & 3.957698 & $0.002335^{* * *}$ & 1997 & -5.166617 & $0.003948 * * *$ & $\mathrm{I}(\mathrm{I})$ \\
\hline $\mathrm{CDP}_{\mathrm{t}}$ & -5.578973 & $0.004400^{* * *}$ & 1976 & -7.866696 & $0.000354^{* * *}$ & $\mathrm{I}(\mathrm{I})$ \\
\hline $\mathrm{PD}_{\mathrm{t}}$ & -3.208422 & $0.003077^{* * *}$ & 1986 & -4.130531 & $0.039232^{* *}$ & $\mathrm{I}(\mathrm{I})$
\end{tabular}

Note: ${ }^{* *},{ }^{* *},{ }^{*}$ are significance levels at $1 \%, 5 \%$ and $10 \%$ respectively. 
Table 4: GLS-Unit Root Test (Carrion-i-Silvestre et al., 2009)

\begin{tabular}{|c|c|c|c|c|c|c|}
\hline & $P_{T}$ & $\mathrm{MP}_{\mathrm{T}}$ & $\mathrm{MZ}_{\mathrm{a}}$ & $M Z_{t}$ & MSB & Break Year \\
\hline$E C F_{t}$ & $\begin{array}{r}15.58528 \\
(7.2936851)\end{array}$ & $\begin{array}{r}14.943543 \\
(7.2936851)\end{array}$ & $\begin{array}{r}-15.790564 \\
(-32.072610)\end{array}$ & $\begin{array}{r}0.17702978 \\
(0.12442987)\end{array}$ & $\begin{array}{r}-2.795400 \\
(-4.0020008)\end{array}$ & 1991-2002-2010 \\
\hline $\mathrm{CO}_{t}$ & $\begin{array}{r}18.964709 \\
(7.2406008)\end{array}$ & $\begin{array}{r}19.240834 \\
(7.2406008)\end{array}$ & $\begin{array}{r}-12.786662 \\
(-33.106480)\end{array}$ & $\begin{array}{r}0.18576648 \\
(0.12259711)\end{array}$ & $\begin{array}{r}-2.3753331 \\
(-4.0592393)\end{array}$ & 1977-1993-2002 \\
\hline$G D$ & $\begin{array}{r}11.563932 \\
(6.1247571)\end{array}$ & $\begin{array}{r}11.088855 \\
(6.1247571)\end{array}$ & $\begin{array}{r}-18.04151 \\
(-31.315537)\end{array}$ & $\begin{array}{r}0.16150843 \\
(0.12811542)\end{array}$ & $\begin{array}{r}-2.913856 \\
(-3.9177577)\end{array}$ & 1978-1992-2003 \\
\hline$P D$ & $\begin{array}{r}11.563932 \\
(6.1247571)\end{array}$ & $\begin{array}{r}11.088855 \\
(6.1247571)\end{array}$ & $\begin{array}{r}-18.041513 \\
(-31.315537)\end{array}$ & $\begin{array}{r}0.16150843 \\
(0.12811542)\end{array}$ & $\begin{array}{r}-2.9138564 \\
(-3.9177577)\end{array}$ & 1966-1978-1981 \\
\hline
\end{tabular}

First Difference

\begin{tabular}{|c|c|c|c|c|c|}
\hline$\Delta \mathrm{ECF}_{\mathrm{t}}$ & $\begin{array}{r}6.570007^{*} \\
(6.9109368)\end{array}$ & $\begin{array}{r}6.022047^{*} \\
(6.9109368)\end{array}$ & $\begin{array}{c}-24.354363^{*} \\
(-34.406241)\end{array}$ & $\begin{array}{l}0.11281449 * \\
(0.12076600)\end{array}$ & $\begin{array}{c}-3.4781559^{*} \\
(-4.1407918)\end{array}$ \\
\hline $\mathrm{CO}_{\mathrm{t}}$ & $\begin{array}{r}7.478304^{*} \\
(8.1325473)\end{array}$ & $\begin{array}{r}7.036786^{*} \\
(8.1325473)\end{array}$ & $\begin{array}{l}-21.460859^{*} \\
(-34.930908)\end{array}$ & $\begin{array}{l}0.10089133^{*} \\
(0.11825864)\end{array}$ & $\begin{array}{l}-2.68 * \\
(-4.09)\end{array}$ \\
\hline $\mathrm{DP}_{\mathrm{t}}$ & $\begin{array}{r}7.332376^{*} \\
(7.5882310)\end{array}$ & $\begin{array}{r}7.530552 * \\
(7.5882310)\end{array}$ & $\begin{array}{r}-21.69314^{*} \\
(-33.981331)\end{array}$ & $\begin{array}{c}0.11172255^{*} \\
(0.12005625)\end{array}$ & $\begin{array}{l}-3.2913388^{*} \\
(-4.0878830)\end{array}$ \\
\hline & $\begin{array}{r}7.478304^{*} \\
(8.1325473)\end{array}$ & $\begin{array}{r}7.036786^{*} \\
(8.1325473)\end{array}$ & $\begin{array}{l}-21.460859^{*} \\
(-34.930908)\end{array}$ & $\begin{array}{l}0.10089133^{*} \\
(0.11825864)\end{array}$ & $\begin{array}{l}-3.2382575^{*} \\
(-4.1405918)\end{array}$ \\
\hline
\end{tabular}

Note: * indicates a significance level of 5\%. Carrion-i-Silvestre et al. (2009).

Table 5: Maki Co-Integration Analysis for CO2 Emissions

\begin{tabular}{l|c|c|c|c}
\multicolumn{1}{c|}{ Regime } & Test-Statistic & CV(5\%) & CV(1\%) & Break Year \\
Regime Shift & $-9.76^{* *}$ & -8.11 & -8.67 & $1985-2001-2008$ \\
Trend and Regime shift & $-11.58 * *$ & -8.81 & -9.43 & $1979-2001-2009$
\end{tabular}

Note: ${ }^{*},{ }^{* *}$ indicate significance level at $5 \%$ and $1 \%$.

Table 6: Maki Co-Integration Analysis for Ecological Footprint

\begin{tabular}{l|l|l|l|c}
\multicolumn{1}{c|}{ Regime } & \multicolumn{1}{|c|}{ Test-Statistic } & \multicolumn{1}{c|}{$C V(5 \%)$} & Break Year \\
Regime Shift & $-11.19^{* *}$ & -8.11 & -8.67 & $1992-1998-2012$ \\
Trend and Regime shift & $-12.40 * *$ & -8.81 & -9.43 & $1991-2001-2009$
\end{tabular}

Note: *, ** indicate significance level at $5 \%$ and $1 \%$. 
Table 7: ARDL BOUND TESTING

$$
\begin{aligned}
& \mathrm{CO}_{2}=\mathrm{f}\left(\mathrm{CDP}_{\mathrm{t}}, \mathrm{GDPSO}_{\mathrm{t}}, \mathrm{PD}_{\mathrm{t}}\right)^{\mathrm{a}} \\
& \mathrm{CO}_{2}=\mathrm{f}\left(\mathrm{GDP}_{\mathrm{t}}, \mathrm{GDPSO}_{\mathrm{t}}, \mathrm{PD}_{\mathrm{t}}, \mathrm{D} 1979, \mathrm{D} 1991, \mathrm{D} 2001\right)^{\mathrm{b}} \\
& \mathrm{ECF}=\mathrm{f}\left(\mathrm{GDP}_{\mathrm{t}}, \mathrm{GDPSO}_{\mathrm{t}}, \mathrm{PD}_{\mathrm{t}} \mathrm{c}^{\mathrm{c}}\right. \\
& \mathrm{ECF}=\mathrm{f}\left(\mathrm{GDP}_{\mathrm{t}}, \mathrm{GDPSO}_{\mathrm{t}}, \mathrm{PD}_{\mathrm{t}}, \mathrm{D} 1991, \mathrm{D} 2001, \mathrm{D} 2009\right)^{\mathrm{d}}
\end{aligned}
$$

F-Statistic

$$
\begin{array}{r}
10.19^{* * *} \\
9.89^{* * *} \\
5.39 * * \\
7.08 * * *
\end{array}
$$

\begin{tabular}{|c|c|c|c|c|}
\hline Variables & $\begin{array}{l}\text { Model-a } \\
\text { Coefficients } \\
\text { (P-Values) }\end{array}$ & $\begin{array}{l}\text { Model-b } \\
\text { Coefficients } \\
\text { (P-Values) }\end{array}$ & $\begin{array}{l}\text { Model-c } \\
\text { Coefficient } \\
\text { (P-Values) }\end{array}$ & $\begin{array}{l}\text { Model-d } \\
\text { Coefficient } \\
\text { (P-Values) }\end{array}$ \\
\hline $\mathrm{GDP}_{\mathrm{t}}$ & $-17.659299 * * *(0.0000)$ & $-22.445747 * * *(0.0000)$ & $-6.666269 * * *(0.0003)$ & $-5.116467 * * *(0.0098)$ \\
\hline GDPSQ $_{t}$ & $0.308227^{* * *}(0.0000)$ & $0.379491^{* * *}(0.0000)$ & $2.549044^{* * *}(0.0018)$ & $0.090221^{* * *}(0.0097)$ \\
\hline$P D_{t}$ & $8.263835 * * *(0.0000)$ & $14.959369 * * *(0.0000)$ & $0.119542 * * *(0.0001)$ & $2.631187^{* * *}(0.0001)$ \\
\hline D1979 ${ }_{\mathrm{t}}$ & - & $-0.347726^{* *}(0.0226)$ & & \\
\hline D1991 & - & $0.171750 * *(0.0332)$ & & $0.028696(0.5484)$ \\
\hline D2001 & - & $0.612800 * * *(0.0055)$ & & $0.237866^{* * * *}(0.0070)$ \\
\hline D2009 & & & & $-0.043375(0.6188)$ \\
\hline Constant & $213.205044^{* * *}(0.0000)$ & $258.397508^{* * *}(0.0000)$ & $81.034768^{* * *}(0.0004)$ & $60.195445^{* *}(0.0166)$ \\
\hline
\end{tabular}

Note: ${ }^{* * *},{ }^{* *},{ }^{*}$ denote the $1 \%, 5 \%$, and $10 \%$ levels of significance, a, b, c, d is Model-a (main model

\begin{tabular}{|c|c|c|c|c|}
\hline $\begin{array}{l}\text { Vari- } \\
\text { ables }\end{array}$ & $\begin{array}{l}\text { Model-a } \\
\text { Coefficients } \\
\text { (P-Values) }\end{array}$ & $\begin{array}{l}\text { Model-b } \\
\text { Coefficients } \\
\text { (P-Values) }\end{array}$ & $\begin{array}{l}\text { Model-c } \\
\text { Coefficient } \\
\text { (P-Values) }\end{array}$ & $\begin{array}{l}\text { Model-d } \\
\text { Coefficient } \\
\text { (P-Values) }\end{array}$ \\
\hline $\mathrm{GDP}_{\mathrm{t}}$ & $-3.676455^{* * *}(0.0000)$ & $-15.132448 * *(0.0429)$ & $-1.612246^{* * *}(0.0048)$ & $11.668401 *(0.0504)$ \\
\hline GDPSO $_{t}$ & $0.084558 * * *(0.0000)$ & $0.127859 * *(0.0326)$ & $0.036708^{* * *}(0.0008)$ & $0.101906 *(0.0939)$ \\
\hline $\mathrm{PD}_{\mathrm{t}}$ & $16.906222^{* * *}(0.0049)$ & $29.045515^{* * *}(0.0000)$ & $0.616490 * * *(0.0076)$ & $1.111966 * * *(0.0032)$ \\
\hline D1979 & - & $-0.040247(0.1960)$ & & \\
\hline D1991 & - & $0.043153^{*}(0.0653)$ & & 0.012127 (0.5209) \\
\hline D2001 & - & $0.077339 * * *(0.0086)$ & & $-0.045395 *(0.0993)$ \\
\hline D2009 & 1 & - & - & $-0.006745(0.8132)$ \\
\hline ECM & $-0.274338 * * *(0.0000)$ & $-0.251256^{* * *}(0.0002)$ & $-0.241851 * * *(0.0015)$ & $-0.42261 * * *(0.0003)$ \\
\hline
\end{tabular}
with CO2), Model-b (CO2 with dummies), Model-c (main model with ECF), and Model-d (ECF with dummies).

Table-8: ARDL Long-Run Analysis

Note: $* * *, * * *$ are $1 \%, 5 \%$, and $10 \%$ levels of significance, and Model-a (CO2 main model), Model-b (CO2 model with year dummies), Model-c (ECF main model), Model-d (ECF model with year dummies) respectively.

Table 9: ARDL- Short Run Results

Note: ${ }^{*}, * *, * * *$ denotes the $10 \%, 5 \%$, and $1 \%$ significance levels, respectively. $1,2,3,4$ denote Model-I (simple one), Model-II (interactive term), Model-III (With Dummies), Model-IV (Dummies and interactive term) SBC. 
Figure 1. Population Density of China

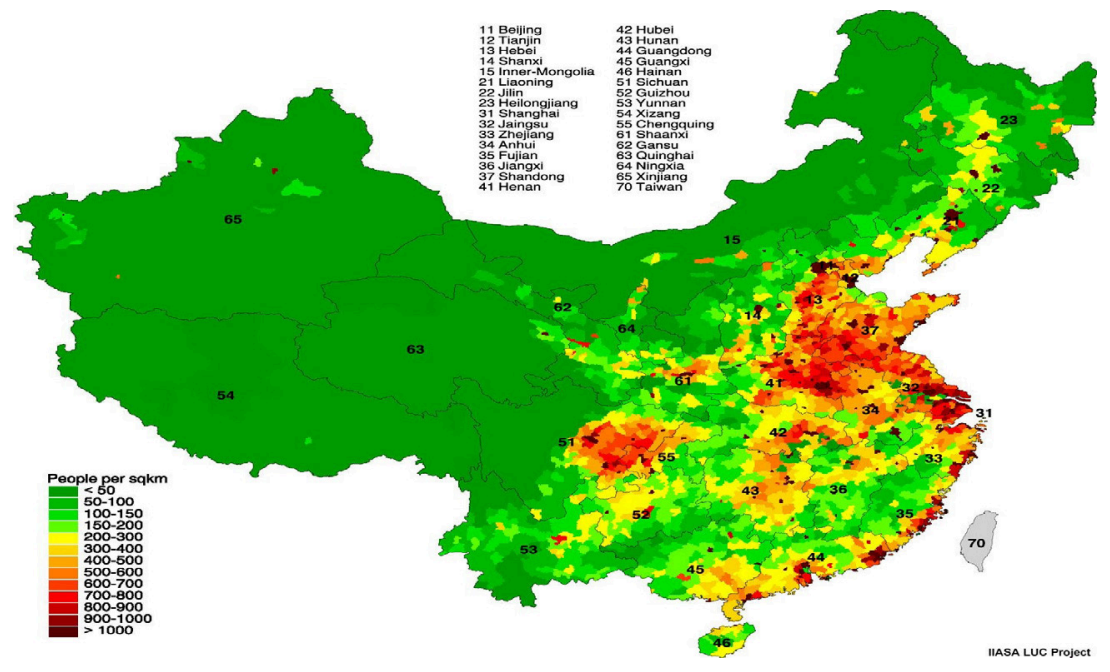

